Pacific Northwest

National Laboratory

Operated by Battelle for the

U.S. Department of Energy

\section{Soil Sampling and Analysis Plan for the McGee Ranch-Riverlands and North Slope Units of the Hanford Reach National Monument}

B. G. Fritz

R. L. Dirkes

December 2004

Prepared for the U.S. Department of Energy

under Contract DE-AC05 -76RL01830 


\title{
DISCLAIMER
}

This report was prepared as an account of work sponsored by an agency of the United States Government. Neither the United States Government nor any agency thereof, nor Battelle Memorial Institute, nor any of their employees, makes any warranty, express or implied, or assumes any legal liability or responsibility for the accuracy, completeness, or usefulness of any information, apparatus, product, or process disclosed, or represents that its use would not infringe privately owned rights. Reference herein to any specific commercial product, process, or service by trade name, trademark, manufacturer, or otherwise does not necessarily constitute or imply its endorsement, recommendation, or favoring by the United States Government or any agency thereof, or Battelle Memorial Institute. The views and opinions of authors expressed herein do not necessarily state or reflect those of the United States Government or any agency thereof.

\author{
PACIFIC NORTHWEST NATIONAL LABORATORY \\ operated by \\ BATTELLE \\ for the \\ UNITED STATES DEPARTMENT OF ENERGY \\ under Contract DE-AC06-76RL01830
}

Ty 


\title{
Soil Sampling and Analysis Plan for the McGee Ranch-Riverlands and North Slope Units of the Hanford Reach National Monument
}

\author{
B. G. Fritz \\ R. L. Dirkes
}

December 2004

Prepared for

the U.S. Department of Energy

under Contract DE-AC05-76RL01830

Pacific Northwest National Laboratory

Richland, Washington 99352 


\section{Summary}

This document describes soil sampling that will be performed on several units of the Hanford Reach National Monument: the McGee Ranch-Riverlands Unit and the North Slope which consists of the Saddle Mountain Unit and the Wahluke Slope Unit. This sampling fulfills a U.S. Department of Energy (DOE) requirement to evaluate the potential for residual radioactive contamination on this land and determine compliance with the requirements of DOE Order 5400.5 prior to radiological release of the property.

DOE Order 5400.5 requires that a request for radiological release criteria, i.e., Authorized Limits, be developed and submitted to the applicable DOE headquarters program office for approval. For the Hanford Site, this is the DOE Office of Environmental Management (EM). The Authorized Limit request, which is based on an annual exposure limit of $100 \mathrm{mrem}$ to the public, was submitted to DOE-EM on December 22, 2003. DOE-EM approved the requested Authorized Limits on March 1, 2004.

The McGee Ranch-Riverlands Unit is located to the north and west of Highway 24 and is bordered by the Columbia River and private land (Figure 1.1). The North Slope consists of two distinct units: the Saddle Mountain Unit and the Wahluke Slope Unit, both located north of the Columbia River. The North Slope units do not include Columbia River islands or riverbank below the high water line.

Soil sampling as defined in this plan will be conducted on the McGee Ranch-Riverlands Unit and North Slope in an effort to demonstrate compliance with the Authorized Limits. Samples will be

collected and analyzed for radioactive constituents identified in the Authorized Limits. The results of these soil samples will be compared to the approved Authorized Limits to determine compliance. 


\section{Contents}

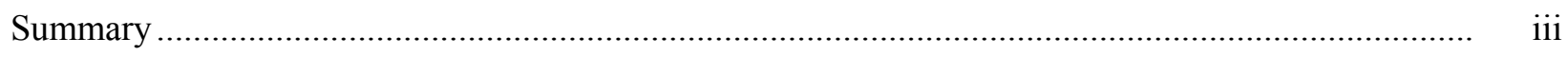

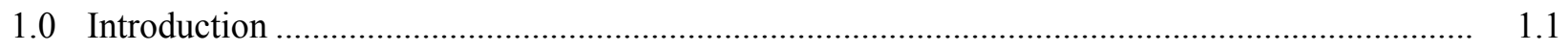

2.0 Sampling Procedure

2.1 Determination of the Number of Samples....................................................................... 2.1

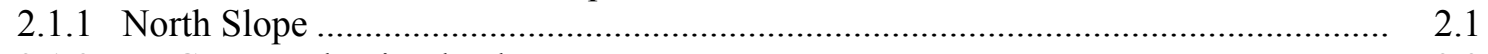

2.1.2 McGee Ranch-Riverlands ............................................................................... 2.2

2.2 Sample Locations ...................................................................................................... 2.3

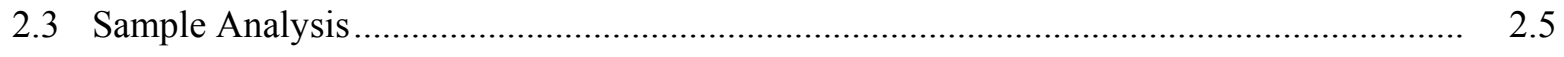

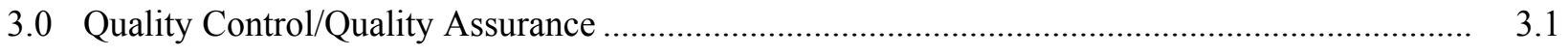

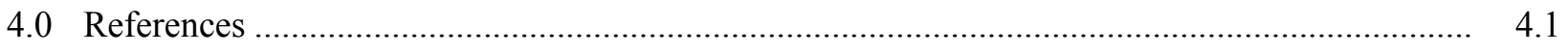

Appendix A - Visual Sample Plan Results for the North Slope Unit

Appendix B - Visual Sample Plan Results for the McGee Ranch-Riverlands Unit

\section{Figures}

1.1 Hanford Reach National Monument with Central Plateau Wind Rose ........................................ 1.2

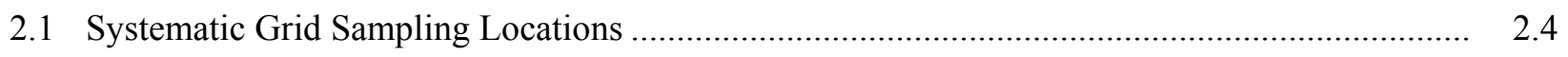

\section{Tables}

2.1 Number of Soil Samples Planned for Collection for the McGee Ranch-Riverlands Unit

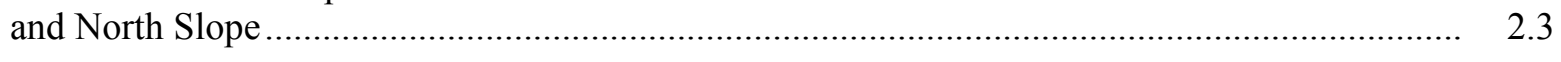

2.2 Predetermined Systematic Grid Sampling Location Coordinates .................................................. 2.4

2.3 Analytes, Detection Limits, and Authorized Limits for the McGee Ranch-Riverlands Unit

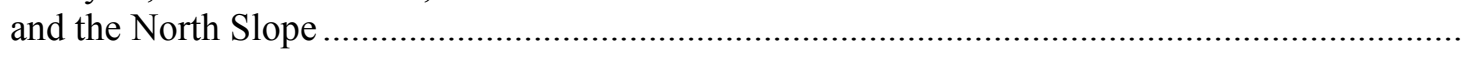




\subsection{Introduction}

The Hanford Reach National Monument (HRNM) consists of several units, including the McGee Ranch-Riverlands Unit and the North Slope made up of the Saddle Mountain Unit and the Wahluke Slope Unit. The McGee Ranch-Riverlands Unit is located to the north and west of Highway 24 and is bordered by the Columbia River and private land (Figure 1.1). The North Slope consists of two distinct units: the Saddle Mountain Unit and the Wahluke Slope Unit, both located north of the Columbia River. The North Slope units do not include Columbia River islands or riverbank below the high water line. The exception to this is Savage Island, which is an intermittent island and is within the North Slope boundary. To fulfill an internal requirement prior to radiological release of property, the U.S. Department of Energy (DOE) must evaluate the potential for residual radioactive contamination on this land, and determine compliance with the requirements of DOE Order 5400.5 (DOE 1993).

DOE Order 5400.5 requires that a request for radiological release criteria, i.e., Authorized Limits, be developed and submitted to the applicable DOE headquarters program office for approval. For the Hanford Site, this is the DOE Office of Environmental Management (EM). The request for Authorized Limits, which is based on an annual exposure limit of 100 mrem to the public, was submitted to DOE-EM on December 22, 2003. DOE-EM approved the requested Authorized Limits on March 1, 2004.

Soil sampling as defined in this plan will be conducted on the McGee Ranch-Riverlands Unit and North Slope in an effort to demonstrate compliance with the Authorized Limits. Samples will be

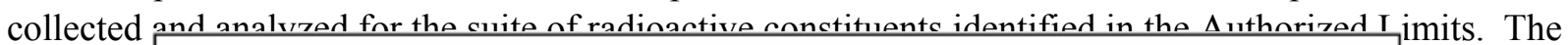

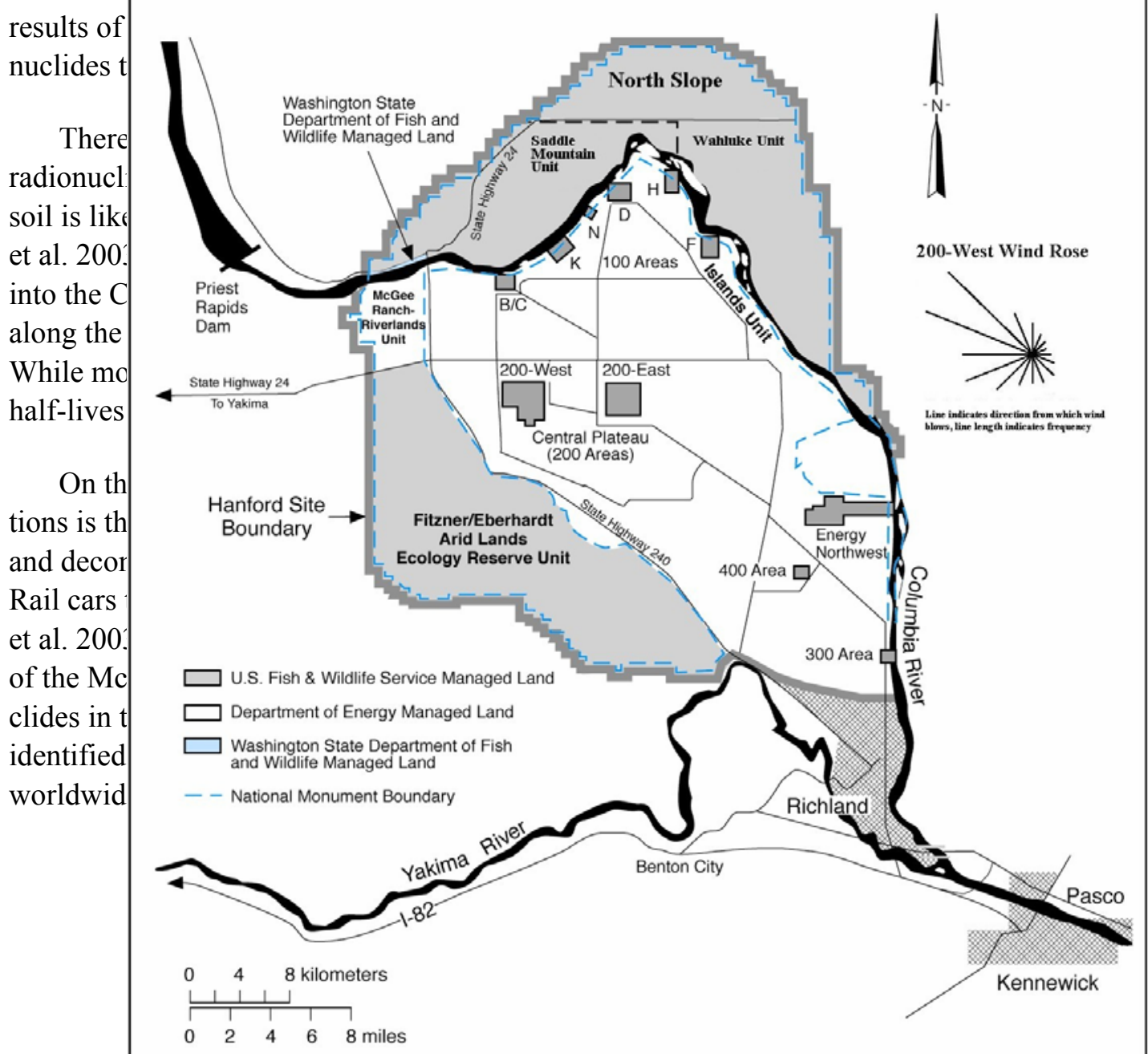

radio-

lted in

North Slope

ons (Fritz

iid effluent

iford Site

bia River.

iciently long

Iford opera-

$\mathrm{d}$ in 1943

inford Site.

yard (Fritz

this portion

radionu-

lands Unit

rial and 
Figure 1.1. Hanford Reach National Monument with Central Plateau Wind Rose

For most radionuclides, vertical movement through the soil is limited (Price 1991), so sampling the surface soil provides the most conservative measure of accumulated radionuclide concentrations and, therefore, the best data for determining compliance with the approved Authorized Limits. The goal and design criteria of this sampling effort is to collect an adequate number of soil samples to determine with a high degree of statistical confidence (99\%) if the concentrations of the radionuclides of concern in soil on the McGee Ranch-Riverlands Unit and North Slope are below the approved Authorized Limits. 


\subsection{Sampling Procedure}

Sample collection will be conducted according to procedures (Hanf and Poston 2004) established and used for the Hanford Surface Environmental Surveillance Project (SESP). The soil collection procedure consists of collecting five sub-samples of the surface soil at each location and compositing them into a single sample submitted for analysis. Each sub-sample location is separated by at least 9 meters, with a minimal amount of vegetative cover, few rocks, and do not appear to have been eroded recently. The five sub-samples are collected with a 10-centimeter-diameter, 2.5-centimeter-deep "cookie cutter" sampling device. Collection staff will record the latitude and longitude of each sampling location for accurate spatial analysis of the data. This procedure is the same one used in the collection of historical soil concentration data evaluated in the historical site assessment (Fritz et al. 2003), resulting in consistent collection techniques as historic soil samples. All sample collection documentation will be consistent with the established SESP sample collection and chain-of-custody protocols.

\subsection{Determination of the Number of Samples}

To determine the number of samples necessary to evaluate the soil concentrations of radionuclides, and provide a high degree of statistical confidence that the Authorized Limits are not exceeded, the Visual Sample Plan (VSP) computer program was used (Gilbert et al. 2001; Hassig et al. 2002). This program was developed to provide a tool for selecting the right number and location of environmental samples so the results of statistical tests performed on data collected via the sampling and analysis plan have the required confidence for decision making. As an added measure, the calculation of the number of samples necessary was done assuming the action level to be one-fourth of the approved Authorized Limits.

\subsubsection{North Slope Units}

The VSP program was run using the statistical information about each radionuclide from historical monitoring data. Strontium-90 is the radionuclide that requires the most samples to meet the statistical requirement of being $99 \%$ confident that North Slope soil concentrations are lower than the approved Authorized Limits. A standard deviation of $0.15 \mathrm{pCi} / \mathrm{g}$ was calculated from historical results for strontium-90 (see Appendix A). To provide a high degree of confidence that the North Slope units comply with the approved Authorized Limits, parameters were set in the VSP program to provide only a $1 \%$ chance of incorrectly concluding the site had concentrations below the approved Authorized Limits. A 5\% chance of incorrectly determining that the site exceeded the Authorized Limits was allowed. It was assumed that due to atmospheric deposition patterns across the North Slope, the results might not be normally distributed; therefore, parameters in the software were set to account for a non-normal distribution of results. The results of VSP indicated that for the North Slope, 20 soil samples are required. This includes a $10 \%$ increase in the sample size to account for missing or unusable data. A detailed description of the VSP results for this sampling plan is included in Appendix A.

While the VSP program is a useful tool in determining the number of samples necessary for determining compliance with Authorized Limits approved by DOE-EM, there are some design assumptions in the VSP program that warrant further consideration in the development of a soil sampling plan. The VSP 
program assumes the terrain to be flat. This is not the case on the North Slope, with elevations ranging from 115 meters in the southeastern corner to 600 meters at the top of the Saddle Mountains. To assure that the sampling design would allow for an evaluation of potential spatial differences, due to elevation or variability in concentrations across the North Slope units, a random start grid pattern rather than randomly selected individual sampling locations was used in selection of the sampling points. The random start grid pattern maintains the requirement for random sample locations and ensures that samples will be collected from different elevations and from locations evenly distributed across the North Slope. To further account for terrain and elevation effects, as well as potential radiological contaminant concentration variability, 10 additional soil samples will be collected at various locations (Section 2.2).

The Columbia River is the southern border of the North Slope units. Historical sampling results and direct radiation monitoring indicate that there is a potential for contamination to have been deposited along the shoreline of the North Slope Unit from Hanford liquid effluent during reactor operations. Results indicated that the most likely place for contamination to have accumulated is in the Savage Island slough at the southeastern corner of the North Slope. To account for the potential elevated contaminant levels along the river shore of the North Slope, an additional 18 samples will be collected from the North Slope shoreline. Since Savage Island was identified in the historical site assessment (Fritz et al. 2003) as having the highest likelihood of elevated levels of radionuclides, 6 of the 18 samples collected along the Columbia River shoreline will be collected from on and around Savage Island and the Savage Island slough.

\subsubsection{McGee Ranch-Riverlands Unit}

The McGee Ranch-Riverlands Unit is significantly smaller than the North Slope units, and is upwind and upriver from Hanford atmospheric emissions and liquid effluent discharge. The small size of the unit and the upwind location make it unlikely that there is significant spatial variability in the soil concentrations as a result of deposition patterns. This allows for an assumption that the soil concentration results will be normally distributed. For developing the scenario for input into VSP to determine sample size, all input parameters (with the exception of the assumption of a normal distribution) were the same as those for the North Slope. The resulting number of samples in the random start grid calculated to be necessary to determine compliance with the approved Authorized Limits is seven. To provide more confidence in the results, five additional samples will be collected across the McGee Ranch-Riverlands Unit at various locations selected by collection staff (Section 2.2).

In the historical site assessment (Fritz et al. 2003), the Riverlands unit classification yard was identified as having the highest potential for radiological contamination as a result of past practices. Although previous work has concluded the Riverlands unit classification yard to have levels of radiological contamination below Washington Administrative Code (WAC) 173-340, Model Toxics Control Act residential standards (DOE et al. 1996), an additional seven soil samples will be collected within the 
boundary of the old classification yard in order to verify previous results, and provide an added measure of confidence that soil concentrations on the entire McGee Ranch-Riverlands Unit are below the approved Authorized Limits.

Overall, 67 soil samples will be collected across the McGee Ranch-Riverlands and the North Slope units. The number of soil samples planned for collection is outlined in Table 2.1. These 67 samples provide a sufficient sample size to allow a statistically valid determination of whether or not concentrations of radionuclides in soil on these HRNM units are below the approved Authorized Limits.

Table 2.1. Number of Soil Samples Planned for Collection for the McGee Ranch-Riverlands Unit and the North Slope Unit

\begin{tabular}{||l|c||}
\hline \multicolumn{1}{|c|}{ Area } & Number of Samples \\
\hline \hline North Slope random start grid & 20 \\
\hline North Slope selected locations & 10 \\
\hline North Slope near Columbia River shore & 18 \\
\hline McGee Ranch-Riverlands Unit random start grid & 7 \\
\hline McGee Ranch-Riverlands Unit selected locations & 5 \\
\hline Riverlands unit classification yard & 7 \\
\hline Total soil samples & $\mathbf{6 7}$ \\
\hline \hline
\end{tabular}

\subsection{Sample Locations}

Using the VSP program with a systematic grid pattern and a random starting location provides good spatial coverage of the units. The sampling locations calculated by the VSP program are illustrated in Figure 2.1, and global positioning system (GPS) coordinates are provided in Table 2.2. It is assumed that due to terrain and a lack of roads in some areas, sampling exactly at the selected locations may not be possible at all locations. Every reasonable effort will be made by collection staff to collect samples from the predetermined locations, but for those locations that are deemed inaccessible, samples will be collected as close as possible to the location determined by the VSP program. For the additional samples being collected to augment the sampling locations determined by the VSP program, samples will be collected from locations that are determined to have a potential for accumulation of radionuclides, or appear to have above average use by members of the public. Samples collected near the Columbia River shoreline on the North Slope will be collected from the riparian zone since defining and identifying the high water line is problematic at some locations along the shoreline. Six samples will be collected on and around Savage Island and the Savage Island slough. The other 12 samples from near the Columbia River shore will be collected at evenly spaced intervals beginning at the Vernita Bridge and ending at the upstream edge of Savage Island. 


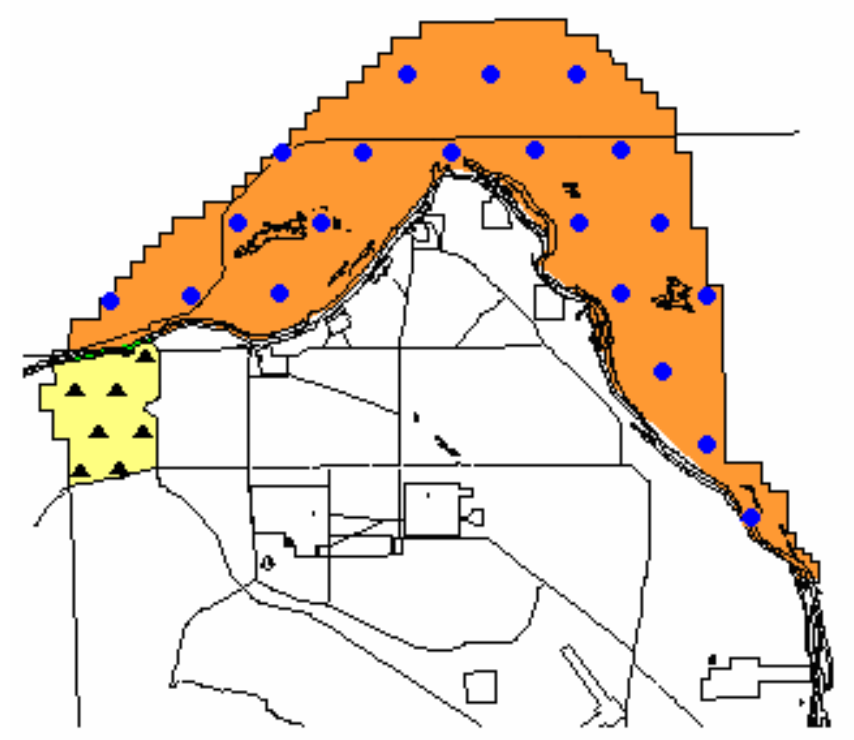

Figure 2.1. Systematic Grid Sampling Locations

Table 2.2. Predetermined Systematic Grid Sampling Location Coordinates

\begin{tabular}{||c|c|c||c|c|c||}
\hline \hline \multicolumn{5}{|c||}{ North Slope } & \multicolumn{3}{c||}{ McGee Ranch-Riverlands } \\
\hline Location & Longitude & Latitude & Location & Longitude & Latitude \\
\hline \hline NS 1 & 119.30813 & 46.54900 & MCG 1 & 119.78656 & 46.57593 \\
\hline NS 2 & 119.33784 & 46.58575 & MCG 2 & 119.75332 & 46.57572 \\
\hline NS 3 & 119.36759 & 46.62249 & MCG 3 & 119.76967 & 46.59568 \\
\hline NS 4 & 119.76402 & 46.66216 & MCG 4 & 119.73642 & 46.59546 \\
\hline NS 5 & 119.70291 & 46.66175 & MCG 5 & 119.78603 & 46.61563 \\
\hline NS 6 & 119.64180 & 46.66131 & MCG 6 & 119.75277 & 46.61542 \\
\hline NS 7 & 119.39738 & 46.65922 & MCG 7 & 119.73586 & 46.63516 \\
\hline NS 8 & 119.33628 & 46.65861 & & & \\
\hline NS 9 & 119.67180 & 46.69797 & & & \\
\hline NS 10 & 119.61065 & 46.69751 & & & \\
\hline NS 11 & 119.42721 & 46.69594 & & & \\
\hline NS 12 & 119.36607 & 46.69535 & & & \\
\hline NS 13 & 119.64065 & 46.73418 & & & \\
\hline NS 14 & 119.57946 & 46.73370 & & & \\
\hline NS 15 & 119.51827 & 46.73320 & & & \\
\hline NS 16 & 119.45709 & 46.73266 & & & \\
\hline NS 17 & 119.39590 & 46.73208 & & & \\
\hline NS 18 & 119.54823 & 46.76989 & & & \\
\hline NS 19 & 119.48700 & 46.76936 & & & \\
\hline NS 20 & 119.42577 & 46.76881 & & & \\
\hline \hline
\end{tabular}




\subsection{Sample Analysis}

A subcontracted analytical laboratory will conduct analysis of soil samples collected. This is the same laboratory used for analysis of routine soil samples collected by SESP, again providing a measure of consistency with historical environmental monitoring data. The suite of radionuclides selected for analysis (Table 2.3) was determined from historical data and the derivation of the approved Authorized Limits (Fritz et al. 2003; Napier et al. 2004). Samples will not be analyzed for americium-241 since there is no reason to expect detectable concentrations. Americium-241 is only included in the Authorized Limits because of its use in research on another unit of the HRNM. The analytical methods will be adequate to detect concentrations well below the approved Authorized Limits. Results for other radionuclides will be obtained as an artifact of the analytical procedures. A gamma scan provides results for 23 radionuclides, and an isotopic plutonium analysis measures concentrations of plutonium-238 as well as plutonium-239/240.

Table 2.3. Analytes, Detection Limits, and Authorized Limits for the McGee Ranch-Riverlands Unit and the North Slope

\begin{tabular}{||l|c|c||}
\hline \multicolumn{1}{|c|}{ Radionuclide } & Analytical Detection Limit (pCi/g) & Authorized Limit (pCi/g) \\
\hline \hline Cobalt-60 & 1 & 11 \\
\hline Cesium-134 & 1 & 20 \\
\hline Cesium-137 & 1 & 46 \\
\hline Europium-152 & 1 & 24 \\
\hline Strontium-90 & 10 & 88 \\
\hline Uranium-234 & 100 & 2400 \\
\hline Uranium-235 & 10 & 190 \\
\hline Uranium-238 & 50 & 770 \\
\hline Plutonium-239/240 & 25 & 480 \\
\hline Americium-241 & NA & 420 \\
\hline NA $=$ & \\
\hline
\end{tabular}




\subsection{Quality Control/Quality Assurance}

Quality control and quality assurance will be maintained through procedures currently in place for the SESP. These include sample collection procedures, records management, chain-of-custody, database management, data verification, and analytical techniques. All samples will be split with a riffle splitter, and half of the sample will be archived to allow for future re-analysis or to analyze for other constituents that may be deemed necessary.

Another quality assurance measure in place is collocated sampling with the Washington Department of Health (WDOH). For the SESP routine soil sampling, the WDOH collects some samples at the same locations as the SESP, and analyzes them independently. This provides an added measure of assurance that the collection procedures and analytical techniques provide good quality data. 


\subsection{References}

DOE - U.S. Department of Energy, Washington State Department of Ecology, and U.S. Environmental Protection Agency. 1996. Declaration of the Record of Decision, USDOE Hanford 100 Area, 100-IU-1, 100-IU-3, 100-IU-4, and 100-IU-5 Operable Units, Hanford Site, Benton County, Washington, U.S. Department of Energy, Richland, Washington.

DOE - U.S. Department of Energy. 1993. Radiation Protection of the Public and Environment. DOE Order 5400.5/Change 2, Washington, D.C.

Fritz BG, RL Dirkes, TM Poston, and RW Hanf. 2003. Historical Site Assessment: Hanford Reach National Monument -- Fitzner-Eberhardt Arid Lands Ecology Reserve (ALE), McGee Ranch, Riverlands, and Wahluke Slope. PNNL-13989, Pacific Northwest National Laboratory, Richland, Washington.

Gilbert RO, JR Davidson, Jr., JE Wilson, and BA Pulsipher. 2001. Visual Sample Plan (VSP) Models and Code Verification. PNNL-13450, Pacific Northwest National Laboratory, Richland, Washington.

Hanf RW and TM Poston. 2004. Surface Environmental Surveillance Procedures Manual. PNL-MA-580, Rev. 4, Pacific Northwest National Laboratory, Richland, Washington.

Hassig NL, RF O’Brien, JE Wilson, BA Pulsipher, RO Gilbert, CA McKinstry, DK Carlson, and DJ Bates. 2002. Visual Sample Plan 2.0 User's Guide. PNNL-14002, Pacific Northwest National Laboratory, Richland, Washington.

Heeb CM. 1994. Radionuclide Releases to the Atmosphere from Hanford Operations, 1944-1972. PNWD-2222 HEDR, Battelle, Pacific Northwest National Laboratory, Richland, Washington.

Napier BA, WE Kennedy, Jr., TA Ikenberry, MM Hunacek, and AM Kennedy. 2004. Technical Basis for the Derivation of Authorized Limits for the Hanford Reach National Monument. PNNL-14531, Pacific Northwest National Laboratory, Richland, Washington.

Price KR. 1991. "The Depth Distribution of Sr-90, Cs-137 and Pu-239/40 in Soil Profile Samples." Radiochemical Acta. 54:145-147. 


\section{Appendix A}

\section{Visual Sample Plan Results \\ for the North Slope Units}




\section{Appendix A \\ Visual Sample Plan Results for the North Slope Units}

\section{A.1 Systematic Sampling Locations for Comparing a Median with a Fixed Threshold (Nonparametric - MARSSIM)}

\section{A.1.1 Summary}

This appendix summarizes the sampling design used, associated statistical assumptions, as well as general guidelines for conducting post-sampling data analysis. Sampling plan components presented here include how many sampling locations to choose and where within the sampling area to collect those samples. The type of medium to sample (i.e., soil, groundwater, etc.) and how to analyze the samples (in situ, fixed laboratory, etc.) are addressed in other sections of the sampling plan.

Table A.1 summarizes the sampling design developed. Figure A.1 shows the sampling locations in the field and Table A.2 lists sampling location coordinates.

Table A.1. Summary of Sampling Design

\begin{tabular}{|l|l||}
\hline Primary objective of design & Compare a site mean or median to a fixed threshold \\
\hline Type of sampling design & Nonparametric \\
\hline Sample placement (location) in the field & Systematic with a random start location \\
\hline Working (null) hypothesis & The median(mean) value at the site exceeds the threshold \\
\hline $\begin{array}{l}\text { Formula for calculating number of sampling } \\
\text { locations }\end{array}$ & Sign Test - MARSSIM version (MARSSIM 2000) \\
\hline Calculated total number of samples & 20 \\
\hline Number of samples on map ${ }^{(\mathrm{a})}$ & 20 \\
\hline Number of selected sample areas ${ }^{(\mathrm{b})}$ & 1 \\
\hline Specified sampling area ${ }^{(\mathrm{c})}$ & $379,000,000 \mathrm{ft}^{2}$ \\
\hline Size of grid/area of grid cell ${ }^{(\mathrm{d})}$ & $4677 \mathrm{ft} / 1.89 \mathrm{E}+007 \mathrm{ft}^{2}$ \\
\hline Grid pattern & Triangular \\
\hline $\begin{array}{l}\text { (a) This number may differ from the calculated number because of 1) grid edge effects, } 2 \text { ) adding judgment } \\
\text { samples, or 3) selecting or unselecting sample areas. } \\
\text { (b) The number of selected sample areas is the number of colored areas on the map of the site. These } \\
\text { sample areas contain the locations where samples are collected. } \\
\text { (c) The sampling area is the total surface area of the selected colored sample areas on the map of the site. } \\
\text { (d) Size of grid/area of grid cell gives the linear and square dimensions of the grid used to systematically } \\
\text { place samples. }\end{array}$ \\
\hline
\end{tabular}




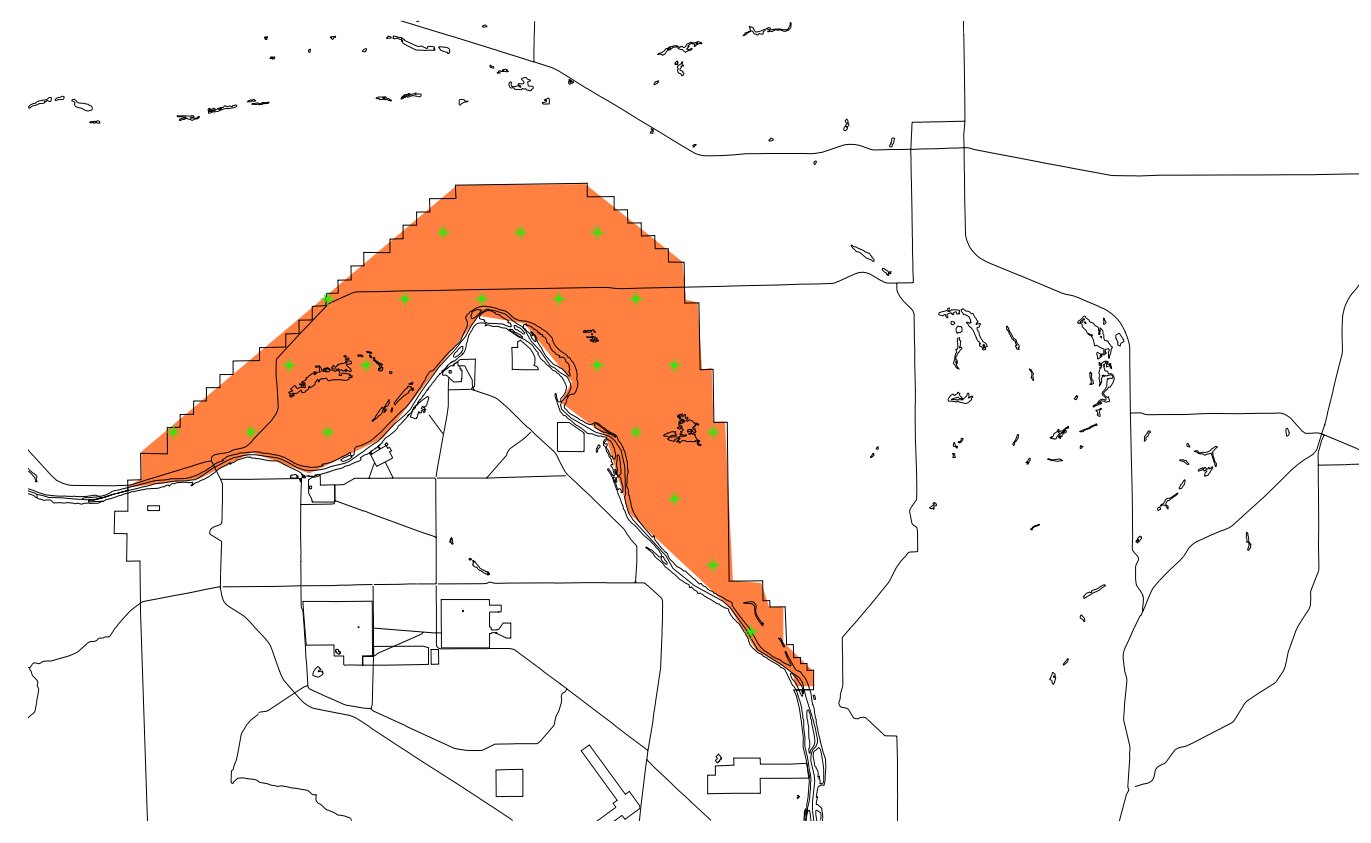

Figure A.1. Sampling Locations at the North Slope Units

Table A.2. Sampling Location Coordinates at the North Slope Units

\begin{tabular}{||c|c|c|c|c|c||}
\hline \multirow{2}{*}{ Location } & \multicolumn{5}{|c|}{ Predetermined North Slope Sampling Locations } \\
\hline & Easting & Northing & & Longitude & Latitude \\
\hline \hline NS 1 & 591397 & 135811 & & 119.30813 & 46.54900 \\
\hline NS 2 & 589059 & 139861 & & 119.33784 & 46.58575 \\
\hline NS 3 & 586720 & 143911 & & 119.36759 & 46.62249 \\
\hline NS 4 & 556322 & 147961 & & 119.76402 & 46.66216 \\
\hline NS 5 & 560998 & 147961 & & 119.70291 & 46.66175 \\
\hline NS 6 & 565675 & 147961 & & 119.64180 & 46.66131 \\
\hline NS 7 & 584382 & 147961 & & 119.39738 & 46.65922 \\
\hline NS 8 & 589059 & 147961 & & 119.33628 & 46.65861 \\
\hline NS 9 & 563337 & 152011 & & 119.67180 & 46.69797 \\
\hline NS 10 & 568013 & 152011 & & 119.61065 & 46.69751 \\
\hline NS 11 & 582044 & 152011 & & 119.42721 & 46.69594 \\
\hline NS 12 & 586720 & 152011 & & 119.36607 & 46.69535 \\
\hline NS 13 & 565675 & 156062 & & 119.64065 & 46.73418 \\
\hline NS 14 & 570352 & 156062 & & 119.57946 & 46.73370 \\
\hline NS 15 & 575029 & 156062 & & 119.51827 & 46.73320 \\
\hline NS 16 & 579705 & 156062 & & 119.45709 & 46.73266 \\
\hline NS 17 & 584382 & 156062 & & 119.39590 & 46.73208 \\
\hline NS 18 & 572690 & 160112 & & 119.54823 & 46.76989 \\
\hline NS 19 & 577367 & 160112 & & 119.48700 & 46.76936 \\
\hline NS 20 & 582044 & 160112 & & 119.42577 & 46.76881 \\
\hline \hline
\end{tabular}




\section{A.1.2 Primary Sampling Objective}

The primary purpose of sampling at this site is to compare a site median value with a fixed threshold. The working hypothesis (or 'null' hypothesis) is that the median value at the site is equal to or exceeds the threshold. The alternative hypothesis is that the median value is less than the threshold. The Visual Sample Plan (VSP) (Gilbert et al. 2001; Hassig et al. 2002) calculates the number of samples required to reject the null hypothesis in favor of the alternative one, given a selected sampling approach and inputs to the associated equation.

\section{A.1.3 Selected Sampling Approach}

A nonparametric systematic sampling approach with a random start was used to determine the number of samples and to specify sampling locations. A nonparametric formula was chosen because the conceptual model and historical information (e.g., historical data from this site or a very similar site) indicate that typical parametric assumptions may not be true.

Both parametric and nonparametric equations rely on assumptions about the population. Typically, however, nonparametric equations require fewer assumptions and allow for more uncertainty about the statistical distribution of values at the site. The trade-off is that if the parametric assumptions are valid, the required number of samples is usually less than if a nonparametric equation was used.

Locating the sample points over a systematic grid with a random start ensures spatial coverage of the site. Statistical analyses of systematically collected data are valid if a random start to the grid is used. One disadvantage of systematically collected samples is that spatial variability or patterns may not be discovered if the grid spacing is large relative to the spatial patterns.

\section{A.1.4 Number of Total Samples: Calculation Equation and Inputs}

The equation used to calculate the number of samples is based on a Sign test (see Gilbert et al. 2001 for discussion). For this site, the null hypothesis is rejected in favor of the alternative one if the median is sufficiently smaller than the threshold.

The formula used to calculate the number of samples is:

$$
n=1.1\left[\frac{\left(Z_{1-\alpha}+Z_{1-\beta}\right)^{2}}{4(\operatorname{Sign} P-0.5)^{2}}\right]
$$

where

$$
\operatorname{Sign} P=\Phi\left[\frac{\Delta}{\mathrm{s}^{2}}\right]
$$

\footnotetext{
$\Phi(\mathrm{z})=$ the cumulative standard normal distribution on $(-\infty, \mathrm{z})$ (see Gilbert et al. 2001 for details)

$n=$ the number of samples

$S=$ the estimated standard deviation of the measured values including analytical error
} 
$\Delta=$ the width of the gray region

$\alpha=$ the acceptable probability of incorrectly concluding the site median is less than the threshold

$\beta=$ the acceptable probability of incorrectly concluding the site median exceeds the threshold

$Z_{1_{-\alpha}}=$ the value of the standard normal distribution such that the proportion of the distribution less than $Z_{1-\alpha}=1-\alpha$

$Z_{1_{-\beta}}=$ the value of the standard normal distribution such that the proportion of the distribution less than $Z_{1-\beta}$ is $1-\beta$.

Note: MARSSIM suggests that the number of samples should be increased by at least $20 \%$ to account for missing or unusable data and uncertainty in the calculated value of $n$. VSP allows a usersupplied percent overage as discussed in MARSSIM (MARSSIM 2000, p. 5-33).

Table A.3. Input Parameters Used to Calculate the Number of Samples Collected on the North Slope

\begin{tabular}{||l|c|}
\hline \multicolumn{1}{|c|}{ Parameter } & Value \\
\hline \hline$S$ & 0.15 \\
\hline$\alpha$ & 0.3 \\
\hline$\beta$ & $1 \%$ \\
\hline$Z_{1-\alpha}$ & $2.32635^{(\mathrm{a})}$ \\
\hline$Z_{1-\beta}$ & $1.64485^{(\mathrm{b})}$ \\
\hline MARSSIM Overage & $10 \%$ \\
\hline $\begin{array}{l}\text { (a) } \\
\text { This value is automatically calculated by VSP } \\
\text { based upon the user defined value of } \alpha .\end{array}$ \\
(b) This value is automatically calculated by VSP \\
based upon the user defined value of $\beta$.
\end{tabular}

Figure A.2 is a performance goal diagram, described in EPA's QA/G-4 guidance (EPA 2000). It shows the probability of concluding the sample area exceeds the threshold value on the vertical axis versus a range of possible true median values for the site on the horizontal axis. This graph contains all of the inputs to the number of samples equation and pictorially represents the calculation. 


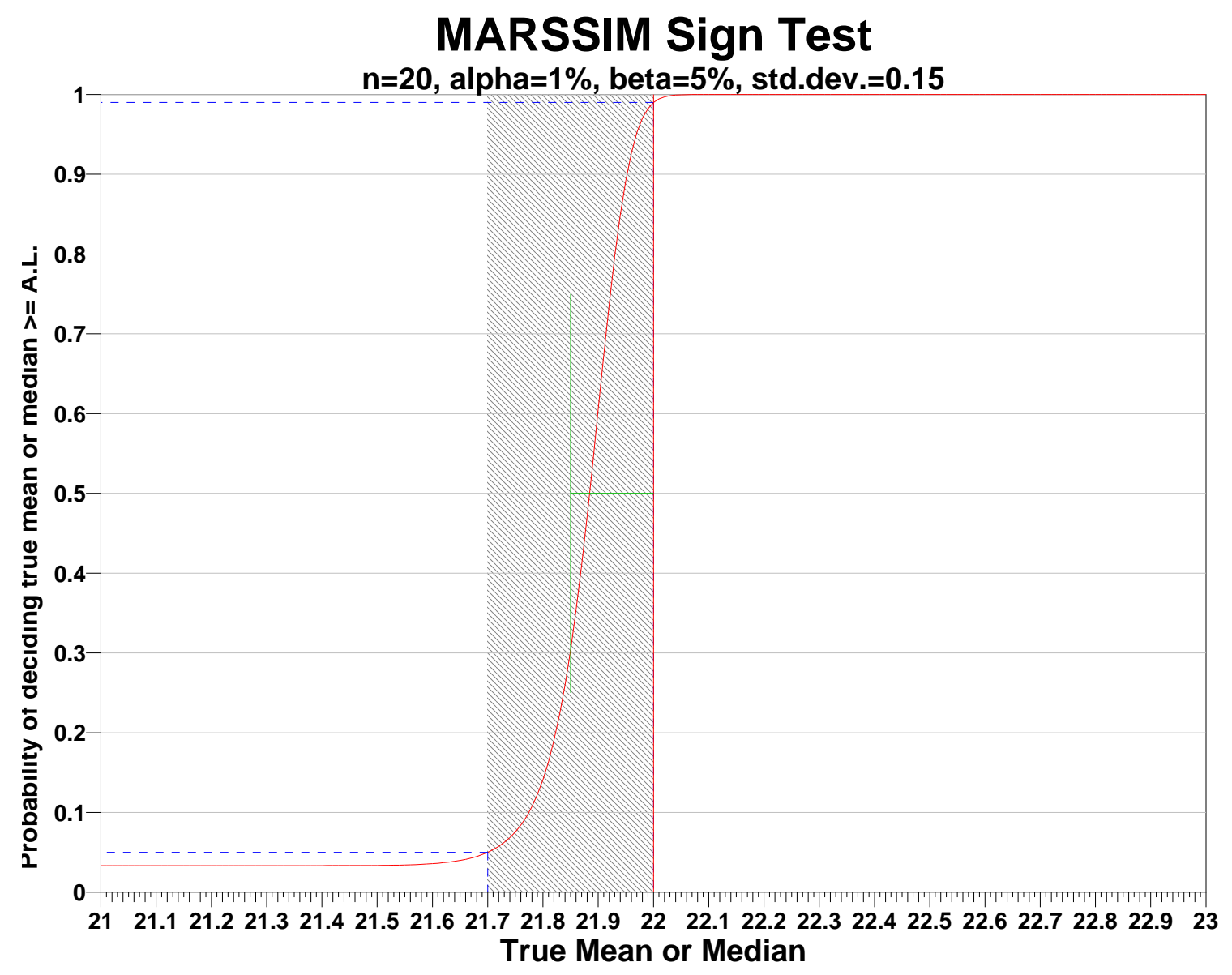

Figure A.2. Performance Goal Diagram

The red vertical line is shown at the threshold (action limit) on the horizontal axis. The width of the gray shaded area is equal to $\Delta$; the upper horizontal dashed blue line is positioned at $1-\alpha$ on the vertical axis; the lower horizontal dashed blue line is positioned at $\beta$ on the vertical axis. The vertical green line is positioned at one standard deviation below the threshold. The shape of the red curve corresponds to the estimates of variability. The calculated number of samples results in the curve that passes through the lower bound of $\Delta$ at $\beta$ and the upper bound of $\Delta$ at 1- $\alpha$. If any of the inputs change, the number of samples that result in the correct curve changes.

\section{A.1.5 Statistical Assumptions}

The assumptions associated with the formulas for computing the number of samples are:

1. The computed sign test statistic is normally distributed.

2. The variance estimate, $S^{2}$, is reasonable and representative of the population being sampled.

3. The population values are not spatially or temporally correlated.

4. The sampling locations will be selected probabilistically 
The first three assumptions will be assessed in a post data collection analysis. The last assumption is valid because the gridded sample locations were selected based on a random start.

\section{A.1.6 Recommended Data Analysis Activities}

Post data collection activities generally follow those outlined in EPA's Guidance for the Data Quality (DQO) Assessment Process (EPA 2000). The data analysts will become familiar with the context of the problem and goals for data collection and assessment. The data will be verified and validated before being subjected to statistical or other analyses. Graphical and analytical tools will be used to verify to the extent possible the assumptions of any statistical analyses that are performed as well as to achieve a general understanding of the data. The data will be assessed to determine whether they are adequate in both quality and quantity to support the primary objective of sampling.

Because the primary objective for sampling for this site is to compare the site median value with a threshold value, the data will be assessed in this context. Assuming the data are adequate, at least one statistical test will be done to perform a comparison between the data and the threshold of interest. Results of the exploratory and quantitative assessments of the data will be reported, along with conclusions that may be supported by them.

\section{A.2 References}

EPA - U.S. Environmental Protection Agency. 2000. Guidance for the Data Quality Objectives (DQO) Process. EPA QA/G-4, EPA/600/R-96/055, U.S. Environmental Protection Agency, Quality Staff, Washington, D.C.

Gilbert RO, JR Davidson, Jr., JE Wilson, and BA Pulsipher. 2001. Visual Sample Plan (VSP) Models and Code Verification. PNNL-13450, Pacific Northwest National Laboratory, Richland, Washington.

Hassig NL, RF O'Brien, JE Wilson, BA Pulsipher, RO Gilbert, CA McKinstry, DK Carlson, and DJ Bates. 2002. Visual Sample Plan 2.0 User's Guide. PNNL-14002, Pacific Northwest National Laboratory, Richland, Washington.

MARSSIM. 2000. Multi-Agency Radiation Survey and Site Investigation Manual (MARSSIM) Rev. 1. NUREG-1575, U.S. Nuclear Regulatory Commission, Washington, D.C. EPA 402-R-97-016, U.S. Environmental Protection Agency, Washington, D.C. 


\section{Appendix B}

Visual Sample Plan Results for the McGee Ranch-Riverlands Unit 


\section{Appendix B \\ Visual Sample Plan Results for the McGee Ranch-Riverlands Unit}

\section{B.1 Systematic Sampling Locations for Comparing a Mean with a Fixed Threshold (Parametric) Summary}

This appendix summarizes the sampling design used, associated statistical assumptions, as well as general guidelines for conducting post-sampling data analysis. Sampling plan components presented here include how many sampling locations to choose and where within the sampling area to collect those samples. The type of medium to sample (i.e., soil, groundwater) and how to analyze the samples (in situ, fixed laboratory, etc.) are addressed in other sections of the sampling plan.

Table B.1 summarizes the sampling design developed. Figure B.1 shows sampling locations in the field and Table B.2 lists sampling location coordinates.

Table B.1. Summary of Sampling Design

\begin{tabular}{||l|l||}
\hline Primary objective of design & Compare a site mean to a fixed threshold \\
\hline Type of sampling design & Parametric \\
\hline Sample placement (location) in the field & Systematic with a random start location \\
\hline Working (null) hypothesis & The mean value at the site exceeds the threshold \\
\hline $\begin{array}{l}\text { Formula for calculating number of } \\
\text { sampling locations }\end{array}$ & Student's t-test \\
\hline Calculated total number of samples & 7 \\
\hline Number of samples on map ${ }^{(a)}$ & 7 \\
\hline Number of selected sample areas ${ }^{(b)}$ & 1 \\
\hline Specified sampling area ${ }^{\text {(c) }}$ & $39,300,000 \mathrm{ft}^{2}$ \\
\hline Size of grid/area of grid cell ${ }^{(\mathrm{d})}$ & $2548 \mathrm{ft} / 5.62 \mathrm{E}+006 \mathrm{ft}^{2}$ \\
\hline Grid pattern & Triangular \\
\hline $\begin{array}{l}\text { (a) This number may differ from the calculated number because of 1) grid edge effects, } \\
\text { 2) adding judgment samples, or 3) selecting or unselecting sample areas. }\end{array}$ \\
$\begin{array}{l}\text { (b) The number of selected sample areas is the number of colored areas on the map of the site. } \\
\text { These sample areas contain the locations where samples are collected. } \\
\text { (c) The sampling area is the total surface area of the selected colored sample areas on the map } \\
\text { of the site. } \\
\text { (d) Size of grid/Area of grid cell gives the linear and square dimensions of the grid used to } \\
\text { systematically place samples. }\end{array}$ \\
\hline
\end{tabular}

B. 1 


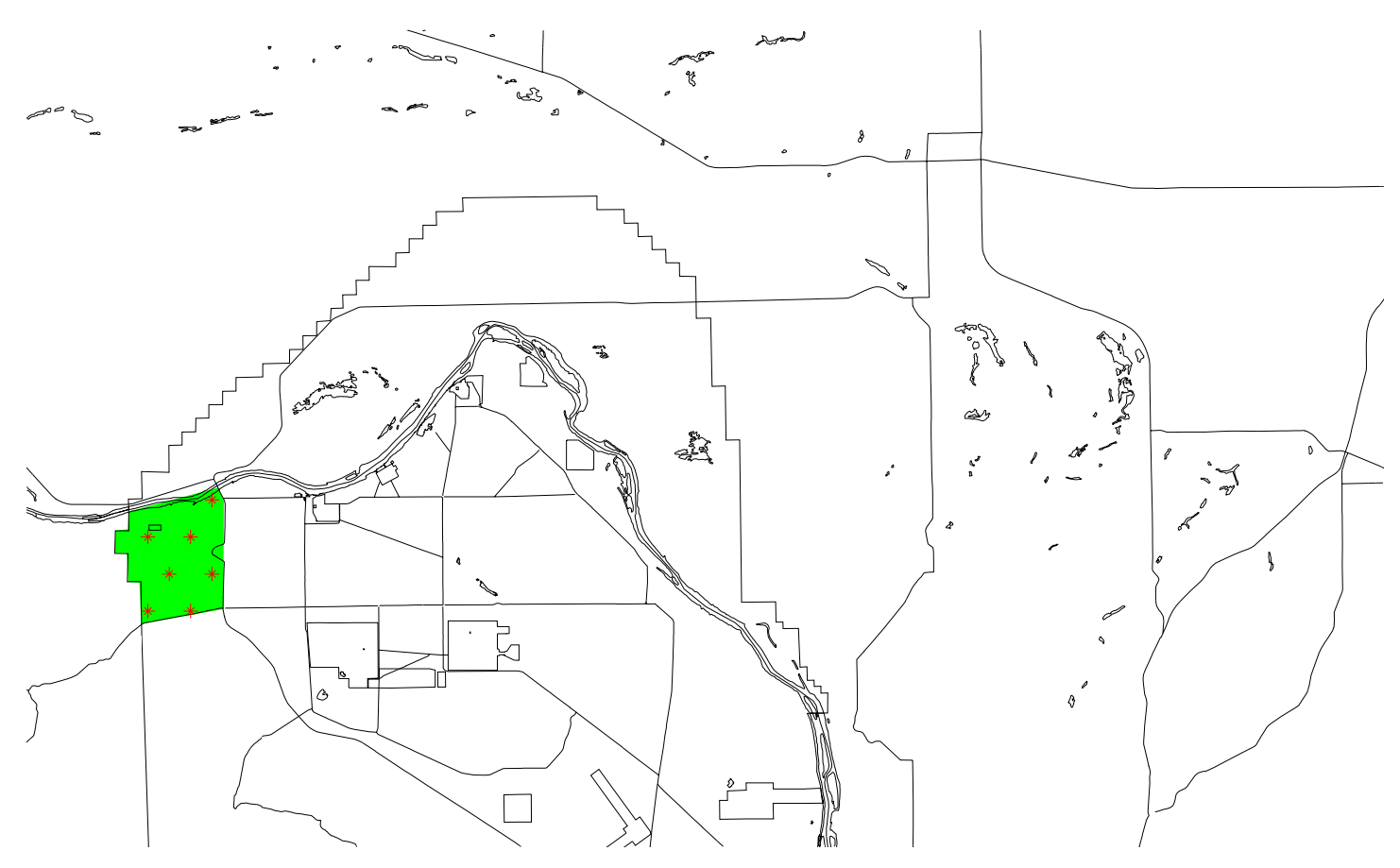

Figure B.1. Sampling Locations at the McGee Ranch-Riverlands Unit

Table B.2. Sampling Location Coordinates McGee Ranch-Riverlands Unit

\begin{tabular}{||c|c|c|c|c|c||}
\hline \multicolumn{5}{|c|}{ Predetermined McGee Ranch-Riverlands Unit Sampling Locations } \\
\hline & \multicolumn{2}{|c|}{ State Plane Coordinates } & & \multicolumn{2}{c||}{ Geographic Coordinates } \\
\hline Location & Easting & Northing & & Longitude & Latitude \\
\hline \hline MCG 1 & 554684 & 138362 & & 119.78656 & 46.57593 \\
\hline MCG 2 & 557231 & 138362 & & 119.75332 & 46.57572 \\
\hline MCG 3 & 555957 & 140568 & & 119.76967 & 46.59568 \\
\hline MCG 4 & 558505 & 140568 & & 119.73642 & 46.59546 \\
\hline MCG 5 & 554684 & 142774 & & 119.78603 & 46.61563 \\
\hline MCG 6 & 557231 & 142774 & & 119.75277 & 46.61542 \\
\hline MCG 7 & 558505 & 144981 & & 119.73586 & 46.63516 \\
\hline \hline
\end{tabular}

\section{B.1.1 Primary Sampling Objective}

The primary purpose of sampling at this site is to compare a mean value with a fixed threshold. The working hypothesis (or 'null' hypothesis) is that the mean value at the site is equal to or exceeds the threshold. The alternative hypothesis is that the mean value is less than the threshold. The Visual Sample Plan (VSP) (Gilbert et al. 2001; Hassig et al. 2002) calculates the number of samples required to reject the null hypothesis in favor of the alternative one, given a selected sampling approach and inputs to the associated equation. 


\section{B.1.2 Selected Sampling Approach}

A parametric systematic sampling approach with a random start was used to determine the number of samples and to specify sampling locations. A parametric formula was chosen because the conceptual model and historical information (e.g., historical data from this site or a very similar site) indicate that parametric assumptions are true. These assumptions will be examined in post-sampling data analysis.

Both parametric and non-parametric equations rely on assumptions about the population. Typically, however, non-parametric equations require fewer assumptions and allow for more uncertainty about the statistical distribution of values at the site. The trade-off is that if the parametric assumptions are valid, the required number of samples is usually less than if a non-parametric equation was used.

Locating the sample points over a systematic grid with a random start ensures spatial coverage of the site. Statistical analyses of systematically collected data are valid if a random start to the grid is used. One disadvantage of systematically collected samples is that spatial variability or patterns may not be discovered if the grid spacing is large relative to the spatial patterns.

\section{B.1.3 Number of Total Samples: Calculation Equation and Inputs}

The equation used to calculate the number of samples is based on a Student's t-test. For this site, the null hypothesis is rejected in favor of the alternative one if the sample mean is sufficiently smaller than the threshold.

The formula used to calculate the number of samples is:

$$
n=\frac{S^{2}}{\Delta^{2}}\left(\mathrm{Z}_{1-\alpha}+\mathrm{Z}_{1-\beta}\right)^{2}=0.5 \mathrm{Z}_{1-\alpha}^{2}
$$

where

$$
\begin{aligned}
n= & \text { the number of samples } \\
S= & \text { the estimated standard deviation of the measured values including analytical error } \\
\Delta= & \text { the width of the gray region } \\
\alpha= & \text { the acceptable probability of incorrectly concluding the site mean is less than the threshold } \\
\beta= & \text { the acceptable probability of incorrectly concluding the site mean exceeds the threshold } \\
Z_{1-\alpha}= & \text { the value of the standard normal distribution such that the proportion of the distribution less } \\
& \text { than } Z_{1-\alpha}=1-\alpha \\
Z_{1-\beta}= & \text { the value of the standard normal distribution such that the proportion of the distribution less } \\
& \text { than } Z_{1-\beta} \text { is } 1-\beta .
\end{aligned}
$$

The values of these inputs that result in the calculated number of sampling locations are shown in Table B.3. 
Table B.3. Input Parameters Used to Calculate the Number of Samples Collected on the McGee RanchRiverlands Unit

\begin{tabular}{|c|c|c|}
\hline \multicolumn{2}{|r|}{ Parameter } & Value \\
\hline$S$ & & 0.15 \\
\hline$\Delta$ & & 0.3 \\
\hline$\alpha$ & & $1 \%$ \\
\hline$\beta$ & & $5 \%$ \\
\hline$Z_{1-\alpha}$ & & $2.32635^{(\mathrm{a})}$ \\
\hline$Z_{1-\beta}$ & & $1.64485^{(\mathrm{b})}$ \\
\hline \multicolumn{3}{|c|}{$\begin{array}{l}\text { (a) This value is automatically calculated by } \\
\text { VSP based upon the user defined value of } \alpha \\
\text { (b) This value is automatically calculated by } \\
\text { VSP based upon the user defined value of } \beta \text {. }\end{array}$} \\
\hline
\end{tabular}

Figure B.2 is a performance goal diagram, described in EPA's QA/G-4 guidance (EPA 2000). It shows the probability of concluding the sample area exceeds the threshold on the vertical axis versus a range of possible true mean values for the site on the horizontal axis. This graph contains all of the inputs to the number of samples equation and pictorially represents the calculation.

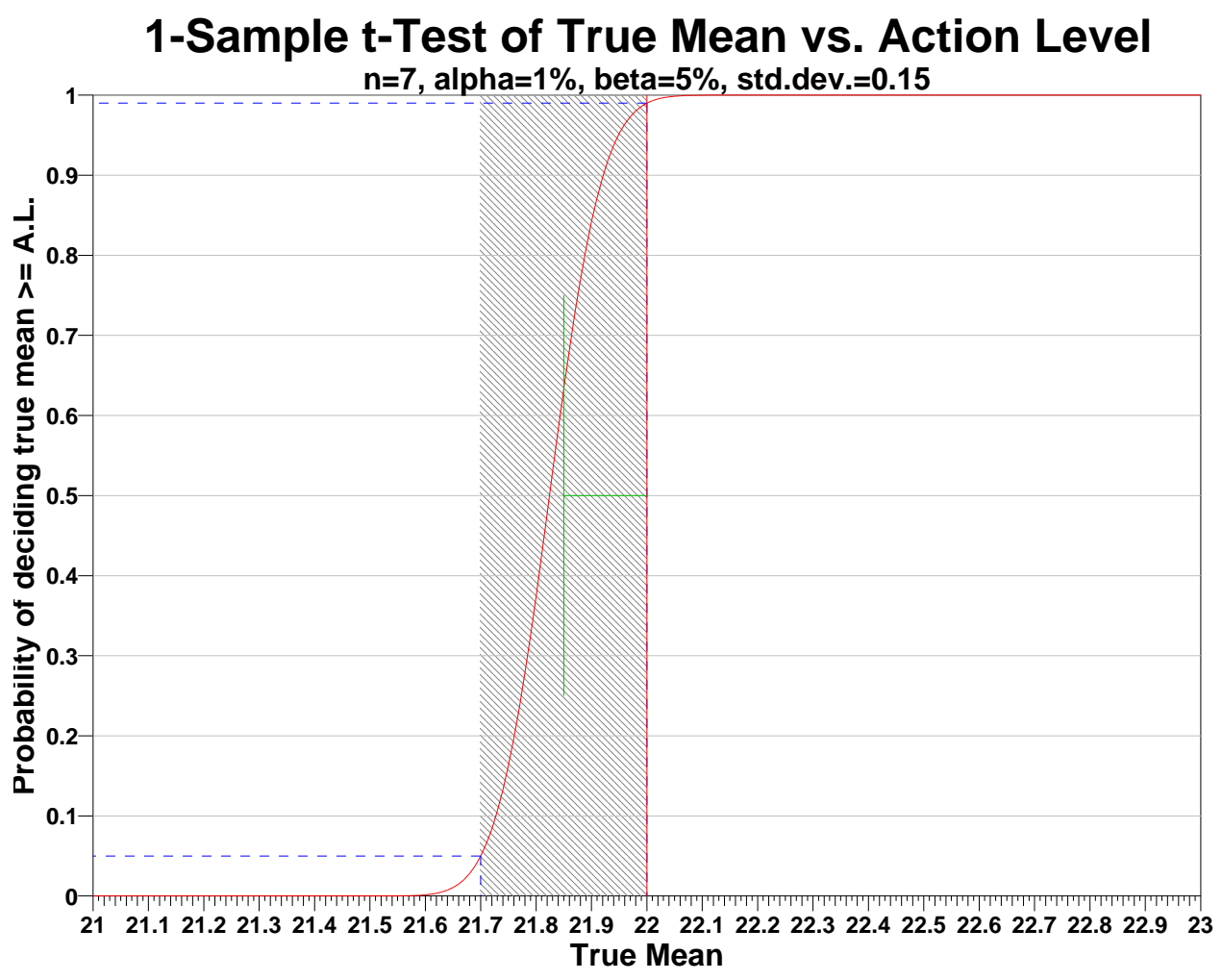

Figure B.2. Performance Goal Diagram 
The red vertical line is shown at the threshold (action limit) on the horizontal axis. The width of the gray shaded area is equal to $\Delta$; the upper horizontal dashed blue line is positioned at 1- $\alpha$ on the vertical axis; the lower horizontal dashed blue line is positioned at $\beta$ on the vertical axis. The vertical green line is positioned at one standard deviation below the threshold. The shape of the red curve corresponds to the estimates of variability. The calculated number of samples results in the curve that passes through the lower bound of $\Delta$ at $\beta$ and the upper bound of $\Delta$ at 1- $\alpha$. If any of the inputs change, the number of samples that result in the correct curve changes.

\section{B.1.4 Statistical Assumptions}

The assumptions associated with the formulas for computing the number of samples are:

1. The sample mean is normally distributed.

2. The variance estimate, $S^{2}$, is reasonable and representative of the population being sampled.

3. The population values are not spatially or temporally correlated.

4. The sampling locations will be selected probabilistically

The first three assumptions will be assessed in a post data collection analysis. The last assumption is valid because the gridded sample locations were selected based on a random start.

\section{B.1.5 Recommended Data Analysis Activities}

Post data collection activities generally follow those outlined in EPA's Guidance for the Data Quality Objectives (DQO) Assessment Process (EPA 2000). The data analysts will become familiar with the context of the problem and goals for data collection and assessment. The data will be verified and validated before being subjected to statistical or other analyses. Graphical and analytical tools will be used to verify to the extent possible the assumptions of any statistical analyses that are performed as well as to achieve a general understanding of the data. The data will be assessed to determine whether they are adequate in both quality and quantity to support the primary objective of sampling.

Because the primary objective for sampling for this site is to compare the site mean value with a threshold value, the data will be assessed in this context. Assuming the data are adequate, at least one statistical test will be done to perform a comparison between the data and the threshold of interest. Results of the exploratory and quantitative assessments of the data will be reported, along with conclusions that may be supported by them.

\section{B.2 References}

EPA - U.S. Environmental Protection Agency. 2000. Guidance for the Data Quality Objectives (DQO) Process. EPA QA/G-4, EPA/600/R-96/055, U.S. Environmental Protection Agency, Quality Staff, Washington, D.C.

Gilbert RO, JR Davidson, Jr., JE Wilson, and BA Pulsipher. 2001. Visual Sample Plan (VSP) Models and Code Verification. PNNL-13450, Pacific Northwest National Laboratory, Richland, Washington. 
Hassig NL, RF O'Brien, JE Wilson, BA Pulsipher, RO Gilbert, CA McKinstry, DK Carlson, and DJ Bates. 2002. Visual Sample Plan 2.0 User's Guide. PNNL-14002, Pacific Northwest National Laboratory, Richland, Washington. 


\section{Distribution}

No. of

Copies

\section{OFFSITE}

N. Ceto

U.S. Environmental Protection Agency

Region 10

Office of Environmental Cleanup

Director - Hanford Project Office

1200 6th Avenue

Seattle, WA 98101

S. Domotor

EH-41/Forrestal Building

U.S. Department of Energy

1000 Independence Ave., S.W.

Washington, D.C. 20585
A. Fredin
Confederated Tribes of the Colville
Reservation
P.O. Box 150
Nespelem, WA 99155
R. Gay
Confederated Tribes of the Umatilla Indian
Reservation
P.O. Box 638
Pendleton, OR 97801
P. Golan
EM-1/Forrestal Building
U.S. Department of Energy
1000 Independence Ave., S.W.
Washington, D.C. 20585
L. Goldstein
Hanford Natural Resources Trustee Council
Washington State Department of Ecology
P.O. Box 47600
Olympia, WA 98504

No. of

Copies

G. Hughes

U.S. Fish and Wildlife Service

3250 Port of Benton Boulevard

Richland, WA 99352-1670

R. Jim, Manager

Environmental Restoration and Waste

Management Program

The Confederated Tribes and Bands of the

Yakama Nation

P.O. Box 151

Toppenish, WA 98948

R. Keck

Energy Northwest

P.O. Box 968

Richland, WA 99352

D. McBaugh

Division of Radiation Protection

Washington State Department of Health

P.O. Box 47890

Olympia, WA 98504-7890

L. Oakes

Energy Northwest

P.O. Box 968

Richland, WA 99352

O. Patt, Jr., Council Chairman

Confederated Tribes of the Warm Springs

Reservation

P.O. Box 1299

Warm Springs, OR 97761

M. Ritter

U.S. Fish and Wildlife Service

3250 Port of Benton Boulevard

Richland, WA 99352

Distr.1 
No. of

Copies

G. Schreckhise, Associate Dean

Washington State University Tri-Cities

2710 University Drive

Richland, WA 99352

L. Seelatsee

Wanapum People

P.O. Box 878

Ephrata, WA 98823

P. Sobotta, Director

ERWM

Nez Perce Tribe

P.O. Box 365

Lapwai, ID 83540

E. Stensgar, Chairman

Coeur d'Alene Tribal Council

P.O. Box 408

Plummer, ID 83851-9704

A. Wallo

EH-41/Forrestal Building

U.S. Department of Energy

1000 Independence Ave., S.W.

Washington, D.C. 20585

J. Watts

Federal Advisory Committee

c/o U.S. Fish and Wildlife Service

3250 Port of Benton Boulevard

Richland, WA 99352
No. of

Copies

\section{ONSITE}

22 DOE Richland Operations Office

K. V. Clarke

A7-75

J. L. Daily

A3- 04

P. F. Dunigan, Jr.

A5-58

W. M. Glines (5)

A6-39

J. B. Hall

A2-15

H. B. Hathaway

A2-15

K. A. Klein

A $7-50$

D. C. Ward (5)

A2-15

S. H. Wisness

A2-15

J. H. Zeisloft

A2-15

DOE Public Reading Room (2) H2-53

Administrative Record (2)

H6-08

\section{Fluor Hanford, Inc.}
A. R. Johnson
H5-26
D. B. Ottley
H5-26

19 Pacific Northwest National Laboratory

E. J. Antonio

K3-54

R. L. Dirkes (5)

K6-75

B. G. Fritz (5)

K6-75

R. H. Hanf

K6-75

B. A. Napier

K3-54

G. P. O'Connor

K6-86

G. W. Patton

K6-75

T. M. Poston

K6-75

Hanford Technical Library (2)

P8-55

LMSI Central Files 